\title{
Secondary Contamination is the Main Source for Spread of Nosema bombycis Resulting in Outbreak of Pebrine Disease in Bombyx mori L.
}

\author{
Satadal Chakrabarty ${ }^{1}$, A.K.Saha ${ }^{1 *}$, B.Manna ${ }^{2}$, and S.Nirmal Kumar ${ }^{1}$ \\ ${ }^{I}$ Central Sericultural Research and Training Institute, Berhampore (W.B.), India \\ ${ }^{2}$ Parasitology Research Unit, Department of Zoology, The University of Calcutta, 35, Ballygunge Circular Road, Kolkata 700019 , India
}

\section{Abstract}

In nature, the population of Nosema bombycis (Microsporidia) causing pebrine disease is small and their development is extremely slow and only few ultimately producing spores. Pebrine infected silkworm, Bombyx mori larvae collected from sericulture field were alive till $3^{\text {rd }}$ generation though the concentration of N.bombycis spore was very high $\left(2.4-3.0 \times 10^{8}\right.$ spores. $\left.\mathrm{mL}^{-1}\right)$. All larvae were died during $4^{\text {th }}$ generation with extremely high concentration of pebrine spores $\left(3.0-4.0 \times 10^{9}\right.$ spores. $\left.\mathrm{mL}^{-1}\right)$ and mostly contain long polar tube (LT). Alternately, all larvae were died immediately (at $3^{\text {rd }}$ stage of $1^{\text {st }}$ generation) when it was artificially inoculated with same concentration of $N$.bombycis spores harvested from field (2.4 $3.0 \times 10^{8}$ spores. $\left.\mathrm{mL}^{-1}\right)$ though concentration of spores harvest was very less $\left(3.0-4.0 \times 10^{6}\right.$ spores. $\mathrm{mL}^{-1}$ ) and mostly contain short polar tube (ST). Artificially pebrine infected male moth when mated with healthy female moth took six generations to develop pebrine disease and all lanvae were died at the $2^{\text {nd }}$ stage with very less spore harvest $\left(3.0-10.0 \times 10^{5}\right.$ spores. $\left.\mathrm{mL}^{-1}\right)$. Survival percentage was increased in all generations $\left(\sim 92.0 \%\right.$ at $4^{\text {th }}$ generation) when silkworm rearing was conducted under new integrated disease management system.

Received : 12 Dec 2013

Accepted : 20 Dec 2013

Keywords:

Nosema bombycis, pebrine disease,

Polar Filament,

(C) 2013 The Korean Society of Sericultural Sciences

Int. J. Indust. Entomol. 27(2), 282-288 (2013)

Environmental spore

\section{Introduction}

Pebrine is a deadliest disease of mulberry silkworm, B. mori L. caused by the pathogen, N.bombycis Nageli, (Microsporidia: Nosematidae). It is transmitted primarily through eggs i.e., transovarian transmission and through the feeding of contaminated leaf, rearing tray, rearing bed, layings, as well as cross-transmission from alternate host secondarily i.e., transovum transmission (Chakrabarty et al., 2013a). Each oval spore measuring 3 - $4 \mu \mathrm{m} \times$ 1.5 - $2 \mu \mathrm{m}$ includes a coiled polar filament that may be $100 \mu \mathrm{m}$ in length. The disease is spread transovarially by environmental spore and secondarily by primary spores. Ultra-structures of the two type of spores are entirely different, primary spore contain short polar tube (ST) with thin wall $(<200 \mathrm{~nm})$; whereas, the environmental spore contain long polar tube (LT) with thick wall (>200 nm). Pasteur (1870) was the first to detect the transmission of pebrine through the eggs i.e., transovarian transmission and he advised for examination of mother moth. It is the standard method followed to control the disease throughout the country. Transovarian transmission has been reported to be sole mechanism by which transmission of

\section{*Corresponding author.}

Dr. Atul Kumar Saha

Scientist D \& Head, Sericulture Division Central Sericultural Research \& Training Institute Central Silk Board: Govt. of India Berhampore- 742101, West Bengal, India

Tel: +919734494570/ FAX: +913482251233

E-mail: sahaatul@rediffmail.com 
the parasites occurs (Kellen et al., 1965, Chapman et al., 1966). It is reported that transmission of microsporidia horizontally by feeding spores produced in male larvae back to larval hosts have been unsuccessful (Kellen et al., 1965) as the size of the spore is larger than the sperm. However, transovum transmission of spore through external surface of genital organ of heavily infected male moths can't be rule out. However, such type of secondary source of contamination of N.bombycis is lacking in the literature. Though, some preliminary studies on veneral transmission of spore have been done by some workers (Patil, 1993). However, we identified that N.bombycis is capable to specify gender of the Bombyx mori and multiplied in male very quickly to spread the infection through transovum transmission (Chakrabarty et al., 2013a).

Therefore, role of transovum transmission of pebrine spore through accessory sex organs / external body surface of male moths in successive generations for transmission of disease was undertaken to find out the sole mechanism of outbreak of disease.

\section{Materials and methods}

\section{Rearing of $1^{\text {st }}$ generation of infected silkworm}

One hundred live cocoons were collected from one farmer's house at Barunighata village, Birbhum district, West Bengal, India. Fifty cocoons were subjected for isolation of $N$. bombycis, pebrine spore. Spores were isolated from live infected pupae and purified by centrifugation at $3000 \mathrm{rpm}$ for $10 \mathrm{~min}$ following new method of pebrine isolation (Chakrabarty et.al, 2013b). After isolation, spores were suspended in $0.85 \% \mathrm{NaCl}$ and stored at $4^{\circ} \mathrm{C}$. Spores were counted using a Neubauer haemocytometer under light microscope (x 600) and determined the inoculum concentration following standard method (Undeen, 1997) and used as stock solution. Fresh spores with 3.0-4.0 × $10^{6}$ spores. $\mathrm{mL}^{-1}$ concentration were inoculated (i.e., artificial infection) to $4^{\text {th }}$ stage $1^{\text {st }} \mathrm{d}$ larvae (Race: M Con1). Other fifty cocoons were allowed for moth emergence in ambient condition (i.e., natural infection). Whole body tissues of both male and female moths were examined under light microscope for detection of pebrine spores after coupling for male moth and oviposition for female moth. Eggs were incubated properly maintaining temperature and humidity as per standard procedure and allowed for hatching in normal condition. Rearing was conducted as per standard procedure ( $1^{\text {st }}$ generation). Again, eggs were prepared utilizing moths generated from $1^{\text {st }}$ rearing and rearing of $2^{\text {nd }}$ generation was conducted following previous procedure i.e., $1^{\text {st }}$ generation.

\section{Rearing $2^{\text {nd }}, 3^{\text {rd }}$ and 4 th generations of infected silkworm}

\section{$2^{\text {nd }}$ generation}

Rearing of $2^{\text {nd }}$ generation were conducted with fifty larvae (Race: Nistari) of $1^{\text {st }}$ brushing (T1) and fifty larvae of $2^{\text {nd }}$ brushing (T2) when eggs were prepared utilizing moths recovered from natural infection of $1^{\text {st }}$ generation. Rearings of $2^{\text {nd }}$ generation were also conducted with fifty larvae of $1^{\text {st }}$ brushing (T3) and fifty larvae (Race: Nistari) of $2^{\text {nd }}$ brushing (T4) when eggs were prepared utilizing moths recovered from artificial infection of $1^{\text {st }}$ generation.

$3^{\text {rd }}$ Generation

Rearing of $3^{\text {rd }}$ generation was conducted with 500 larvae when eggs were prepared utilizing moths recovered from natural infection of $2^{\text {nd }}$ generation (T2).

\section{$4^{\text {th }}$ Generation}

Rearing of $4^{\text {th }}$ generation was conducted with 1000 larvae when eggs were prepared utilizing moths recovered from natural infection of $3^{\text {rd }}$ generation (T2).

\section{Rearing $2^{\text {nd }}, 3^{\text {rd }}$ and $4^{\text {th }}$ generations of infected silkworm with protection}

All the procedure was same as Rearing $2^{\text {nd }}, 3^{\text {rd }}$ and $4^{\text {th }}$ generations. However, these experiments were conducted in two separate batches, one with protection using existing disease management systems, using 'Labex' as bed disinfectant and ' $5 \%$ Bleaching powder' as room disinfectant and other with new disease management system using 'Sericillin' as bed disinfectant and 'fumigant chemicals' as room disinfectant.

\section{Rearing $3^{\text {rd }}$ generations of infected male with healthy female}

Here, we have crossed the fully infected male moths (1.0-1.2 
Satadal Chakrabarty et al.

Secondary contamination of Nosema bombycis resulting in pebrine disease in Bombyx mori L.

Table 1. Comparative performances of N.bombycis at different metamorphic stage of B. mori L. during artificial and natural infection (data in parenthesis indicates the standard error of mean)

\begin{tabular}{|c|c|c|c|c|c|c|}
\hline$\#$ & Race & Type of study & Stage of silkworm & $\begin{array}{l}\text { No. of } \\
\text { sample }\end{array}$ & $\begin{array}{l}\text { Intensity of Infection } \\
\text { (spores. } \mathrm{mL}^{-1} \text { ) }\end{array}$ & $\begin{array}{c}\text { Surviva } \\
(\%)\end{array}$ \\
\hline 1 & Nistari & $\begin{array}{l}\text { Natural infection } \\
\text { (1st generation) }\end{array}$ & Pupa $2^{\text {nd }} d$ & 50 & $\begin{array}{c}2.4-3.0 \times 10^{8} \\
\left(6.0 \times 10^{6}\right)\end{array}$ & 87.2 \\
\hline 2 & M Con1 & $\begin{array}{l}\text { Artificial inoculation } \\
\text { (1st generation) }\end{array}$ & $\begin{array}{c}\text { Larva at } 4^{\text {th }} \text { stage } \\
1 \text { st } d\end{array}$ & 50 & $\begin{array}{c}3.0-4.0 \times 10^{6} \\
\left(1.0 \times 10^{5}\right)\end{array}$ & 1.50 \\
\hline 3 & Nistari & $\begin{array}{l}\text { Natural infection } \\
\text { (2nd generation) }\end{array}$ & Larva under $2^{\text {nd }}$ moult & 50 & $\begin{array}{c}1.0-1.2 \times 10^{7} \\
\left(2.0 \times 10^{6}\right)\end{array}$ & 94.0 \\
\hline 4 & Nistari & do & Larva at $3^{\text {rd }}$ stage & 50 & $\begin{array}{r}1.0 \times 10^{7} \\
\left(1.0 \times 10^{6}\right)\end{array}$ & 82.3 \\
\hline 5 & Nistari & do & Larva at $4^{\text {th }}$ stage & 50 & $\begin{array}{r}1.0 \times 10^{7} \\
\left(1.2 \times 10^{6}\right)\end{array}$ & 75.6 \\
\hline 6 & Nistari & do & Larva at $5^{\text {th }}$ stage & 50 & $\begin{array}{c}\times 10^{7} \\
\left(1.0 \times 10^{6}\right)\end{array}$ & 72.5 \\
\hline 7 & Nistari & do & Pupa & 50 & $\begin{array}{c}\times 10^{7} \\
\left(1.0 \times 10^{6}\right)\end{array}$ & 67.5 \\
\hline 8 & Nistari & do & Moth & 50 & $\begin{array}{c}\times 10^{7} \\
\left(1.0 \times 10^{6}\right)\end{array}$ & 62.3 \\
\hline
\end{tabular}

Table 2. Fitness Efficiency Performance of B. mori L. during artificial and natural infection

\begin{tabular}{|c|c|c|c|c|c|c|c|}
\hline$\#$ & Race & Date & Type of study & $\begin{array}{c}\text { Survival } \\
(\%)\end{array}$ & $\begin{array}{l}\text { Layings } \\
\text { (No) }\end{array}$ & $\begin{array}{l}\text { Fecundity } \\
\text { (No) }\end{array}$ & $\begin{array}{c}\text { Hatching } \\
(\%)\end{array}$ \\
\hline 1 & Nistari & $\begin{array}{c}\text { D/C: } \\
24.04 .2012\end{array}$ & $\begin{array}{l}\text { Natural infection } \\
\text { (1st generation) }\end{array}$ & 87.2 & 20 & 334 & 88.12 \\
\hline 2 & MCon1 & $\begin{array}{c}\text { D/l: } \\
29.04 .2012\end{array}$ & $\begin{array}{l}\text { Artificial inoculation } \\
\text { (1st generation) }\end{array}$ & 1.82 & & All moths died & \\
\hline 3 & Nistari & $\begin{array}{c}D / B: \\
15-16.05 .12\end{array}$ & $\begin{array}{l}\text { Natural infection } \\
\text { (2nd generation) }\end{array}$ & 62.3 & 15 & 249.5 & 86 \\
\hline
\end{tabular}

$\times 10^{7}$ spores. $\mathrm{mL}^{-1}$ ) recovered from rearing $3^{\text {rd }}$ generations with healthy female moths. We have continued the generations with recording survival percentage and intensity of infection.

\section{Results and Discussion}

Nosema could produce two spores from sporont (Ishiwara, 1969). Sporont of N.bombycis usually produced two sporoblast (Lai and Canning, 1983). The first populations of spores mainly cause the spread of the parasite in the epithelium. The second population of spore is formed later on for adapting to survive outside the host (Graaf et al., 1994). Early spores and environmental spores are immature and variants of the same spore type, normally occurs in different tissues in the host (Larson, 1999).

In rearing of $1^{\text {st }}$ generation of infected silkworm (experiment-I), all the larvae were died when the larvae were artificially infected with same inoculums concentration of pebrine spore harvested from the moths collected from the field (3.0-4.0 × $10^{6}$ spores. $\mathrm{mL}^{-1}$ ). However, the larvae were survived harbouring the same concentration of pebrine spore harvested from the moths collected from the field (3.0-4.0 × $10^{6}$ spores.mL $\left.{ }^{-1}\right)$ and larvae completed the life cycle though survival percentage were decreased to $62.3 \%$ where intensity of spore were remain almost same concentrations and constant $\left(1.0 \times 10^{7}\right.$ spores. $\mathrm{mL}^{-1)}$ for all larval stages, pupal stage and moth (Table 1 and 2). Some of the 
Table 3. Comparative performances at different metamorphic stage of B. mori L. during different brushing practice at artificial and natural infection (data in parenthesis indicates the standard error of mean)

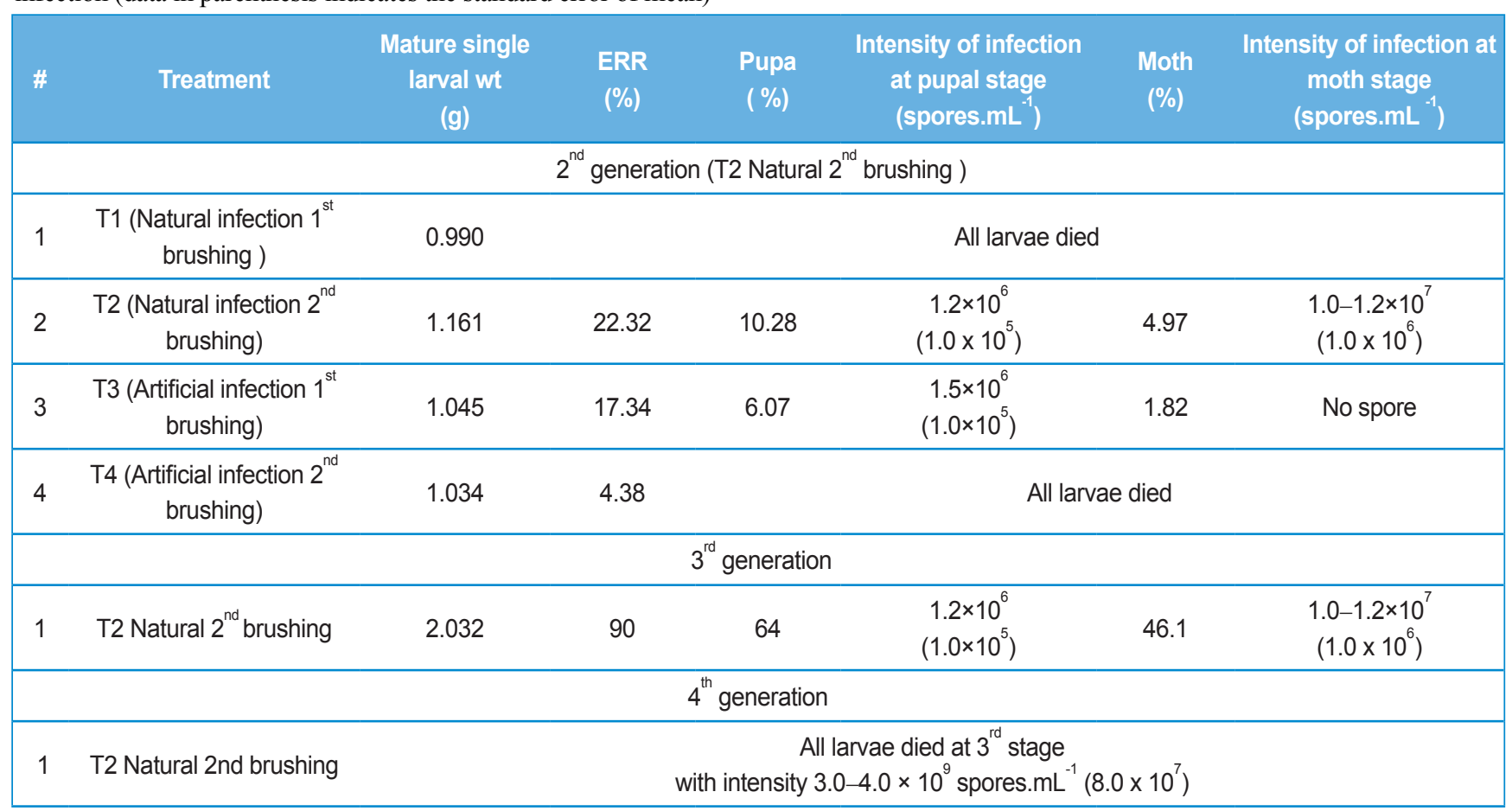

new factor is responsible in the evolution of pathogens as well as variability in host specificity so that their multiplication rate and virulency are restricted in the same host and host of the same origin are only survived. Alternately, artificially infected larvae were died due to loosing the originality of host specificity.

In rearing of $2^{\text {nd }}, 3^{\text {rd }}$ and $4^{\text {th }}$ generation of infected silkworm (experiment-II), all artificially infected larvae were died in $1^{\text {st }}$ generation. But larvae were died in $4^{\text {th }}$ generation when silkworm rearing was conducted in natural condition. In this case, intensity of infection $\left(3.0-4.0 \times 10^{9}\right.$ spores.mL $\left.{ }^{-1}\right)$ was increased and survival percentage was decreased till $3^{\text {rd }}$ generation and at last all larvae were died in $4^{\text {th }}$ generation. Two contrasting results were observed in this experiment. Intensity of infection was more in naturally infected $1^{\text {st }}$ brushing larvae $\left(3.0-4.0 \times 10^{9}\right.$ spores. $\left.\mathrm{mL}^{-1}\right)$ whereas, it is more in $2^{\text {nd }}$ brushing larvae for artificial infection $\left(1.0 \times 10^{8}\right.$ spores. $\left.\mathrm{mL}^{-1}\right)$ before their death. Alternately, survival percentage was more in $2^{\text {nd }}$ brushing larvae (ERR $\sim 22.32 \%)$ infected naturally whereas, it is more in $1^{\text {st }}$ brushing larvae infected artificially (ERR $\sim 17.34 \%$ ). It was very much interesting to observe that all the larvae were survived in $2^{\text {nd }}$ generation when the larvae contain full of pebrine spore (3.0$4.0 \times 10^{7}$ spores. $\mathrm{mL}^{-1}$ ) when larvae infected naturally and finally, all larvae were died in $3^{\text {rd }}$ generation before resume to $3^{\text {rd }}$ stage and contain full of pebrine spore $\left(3.0-4.0 \times 10^{9}\right.$ spores.mL $\left.{ }^{-1}\right)$ (Table 3). In rearing of $2^{\text {nd }}, 3^{\text {rd }}$ and $4^{\text {th }}$ generation of infected silkworm with protection (experiment-III), all the naturally infected larvae were died in $4^{\text {th }}$ generation when rearing was conducted in natural condition and artificially infected larvae were died in $1^{\text {st }}$ generation with existing disease management system. But the survival percentage were increased in all generations when rearing was conducted with new system of management. It was surprised that more than $98 \%$ larvae were survived during $4^{\text {th }}$ generation when rearing was conducted with new system of management and no spore was observed in moth under microscope (Table 4).

In rearing of $3^{\text {rd }}$ generation of infected male with healthy male (experiment- $I V$ ), when artificially infected male moth were mated with healthy female then all offspring were died resume from $1^{\text {st }}$ moult at $6^{\text {th }}$ generation and develop pebrine disease though very less spore harvest $\left(3.0-10.0 \times 10^{5}\right.$ spores. $\mathrm{mL}^{-1)}$ was recorded. We have not recorded any spore till $5^{\text {th }}$ generation. Besides, all the pre cocoon and post cocoon parameters at $5^{\text {th }}$ generation revealed that the lot was healthy as well as robust considering Effective Rearing Rate ( $75 \%)$, single mature larval weight ( 2.496 g), Shell \% ( 13.0), Filament Length ( 271 m), 
Table 4. Comparative performances of management for control of pebrine disease of B. mori L. using existing system of management and new integrated system of management.

\begin{tabular}{|c|c|c|c|c|c|c|c|c|c|}
\hline$\#$ & $\begin{array}{l}\text { Mature larval } \\
\text { wt at } 5^{\text {th }} \text { stage } \\
\text { (g) }\end{array}$ & $\begin{array}{l}\text { ERR } \\
(\%)\end{array}$ & $\begin{array}{c}\text { Pupation } \\
(\%)\end{array}$ & $\begin{array}{c}\text { Intensity of } \\
\text { infection at pupal } \\
\text { stage } \\
\text { spores.mL }\end{array}$ & $\begin{array}{l}\text { Moth } \\
(\%)\end{array}$ & $\begin{array}{c}\text { Intensity of } \\
\text { infection at moth } \\
\text { stage } \\
\text { spores.mL }\end{array}$ & $\begin{array}{l}\text { No of laying } \\
\text { by female } \\
\text { (No) }\end{array}$ & $\begin{array}{l}\text { Fecundity } \\
\text { (No) }\end{array}$ & Hatching (\%) \\
\hline \multicolumn{10}{|c|}{$3^{\mathrm{RD}}$ GENERATION (Treatment with existing systems) } \\
\hline 1 & 2.032 & 90.0 & 88 & $1.2 \times 10^{6}$ & 64 & $1.0-1.2 \times 10^{7}$ & 20 & 275 & 96 \\
\hline \multicolumn{10}{|c|}{$3^{\mathrm{RD}}$ GENERATION (Treatment with new system of management) } \\
\hline 1 & 2.173 & 92.0 & 90 & No spore & 85 & No spore & 42 & 322 & 98 \\
\hline \multicolumn{10}{|c|}{$4^{\text {TH }}$ GENERATION (Treatment with existing systems) } \\
\hline \multicolumn{10}{|c|}{ All worms were died at $3^{\text {rd }}$ stage $\left(3.0-4.0 \times 10^{9}\right.$ spores. $\left.\mathrm{mL}^{-1}\right)$} \\
\hline \multicolumn{10}{|c|}{$4^{\mathrm{TH}}$ GENERATION (Treatment with new system of management) } \\
\hline 1 & 2.223 & 90.0 & 88 & No spore & 85 & No spore & 63 & 329 & 98 \\
\hline
\end{tabular}

Table 5. Secondary contamination of pebrine disease in successive generations in B.mori.

\begin{tabular}{|c|c|c|c|c|c|c|c|c|}
\hline \multicolumn{9}{|c|}{ (Healthy female $x$ Pebrine infected male from $3^{\text {rd }}$ generation of Experiment-II) } \\
\hline$\#$ & Generation & Race & $\mathrm{D} / \mathrm{B}$ & D/S & $\begin{array}{c}\text { Hatch } \\
(\%)\end{array}$ & No of larvae & $\begin{array}{l}\text { Larval weight } \\
\text { (g) }\end{array}$ & $\begin{array}{l}\text { ERR } \\
(\%)\end{array}$ \\
\hline 1 & $\mathrm{~F} 1$ & Nistari & 26.08 .12 & 15.09.12 & 93.56 & 500 & 2.163 & 72.72 \\
\hline 2 & $\mathrm{~F} 2$ & Nistari & 15.11.12 & 09.12 .12 & 89.35 & 500 & 2.154 & 73.86 \\
\hline 3 & F3 & Nistari & 31.01 .13 & 25.02 .13 & 91.68 & 500 & 2.176 & 73.60 \\
\hline 4 & $\mathrm{~F} 4$ & Nistari & 26.03 .13 & 15.04 .13 & 94.24 & 500 & 1.988 & 75.68 \\
\hline 5 & F5 & Nistari & 16.05 .13 & 04.06 .13 & 88.45 & 500 & 2.496 & 74.56 \\
\hline 6 & F6 & Nistari & 18.07.13 & & larvae $n$ & lied at a time & fter 1st moulting & \\
\hline
\end{tabular}

Non-breakable Filament length ( 261 m), Denier (1.91) Fitness Efficiency test i.e., Grainage performance (Table 5 and 6) . Besides, the lot performed better in all the favourable and nonfavourable seasons.

Time taken for establishment of the pathogen for completion of its life cycle and production of spores depends on inoculum load and other environmental factors (Steinhaus and Huges, 1949). We have observed in our previous study that spore harvest was more in male moth compared to that in female moth though the inoculum concentration, source of pathogen and the rearing were conducted in the same environment (Chakrabarty et al., 2013b). The physiological changes in the insect might have possibly influenced the developmental cycle of the parasite to switch on from a predominantly vegetative stage to sporogony, resulting in an increasing spore production. Spore production had reached a stationary phase and yielded similar amounts of spore of $N$. acridiophagus and $N$. cuneatum in larvae of Melanoplus asnguinipes after $20 \mathrm{~d}$ of inoculation with $10^{4}$ and $10^{6}$ spores compared to lower spore yields which were continued in spore multiplication stage when inoculated with $10^{2}$ spores (Cali, 1970). If development is allowed to proceed to the stationary phase, multiplication of the parasite is greater with lower concentrations than with higher concentrations (Kawarabata and Ishihara, 1984). But there is an apparent increase in multiplication with increased concentrations during the exponential phase and the difference between the multiplications of spore with the high and low initial spore concentration is narrow. Multiplication of pathogens depends upon the age of silkworm, time and other indirect 
Table 6. Intensity of infection and reeling performance of secondary contamination of pebrine disease in successive generations in B.mori. (Healthy female $x$ Pebrine infected male from $3^{\text {rd }}$ generation of Experiment-II)

\begin{tabular}{|c|c|c|c|c|c|c|c|c|}
\hline$\#$ & Generation & $\begin{array}{l}\text { SCW } \\
(\mathrm{g})\end{array}$ & $\begin{array}{l}\text { ssw } \\
\text { (g) }\end{array}$ & $\begin{array}{l}\text { Shell } \\
(\%)\end{array}$ & $\begin{array}{l}\text { Intensity of infection } \\
\text { (spores.mL } L^{-1} \text { ) }\end{array}$ & $\begin{array}{l}\mathrm{FL} \\
(\mathrm{m})\end{array}$ & $\begin{array}{l}\text { NBFL } \\
(\mathrm{m})\end{array}$ & $\mathrm{Dr}$ \\
\hline 1 & F1 & 0.983 & 0.120 & 12.18 & Not observed & 265 & 239 & 1.96 \\
\hline 2 & $\mathrm{~F} 2$ & 0.972 & 0.108 & 11.11 & Not observed & 259 & 245 & 1.98 \\
\hline 3 & F3 & 1.169 & 0.150 & 12.83 & Not observed & 273 & 256 & 1.60 \\
\hline 4 & F4 & 1.065 & 0.143 & 13.43 & Not observed & 255 & 238 & 1.73 \\
\hline 5 & F5 & 0.919 & 0.119 & 13.00 & Not observed & 271 & 261 & 1.91 \\
\hline 6 & F6 & All larvae w & at a tin & 1st moulting & $3.0-10.0 \times 10^{5}$ & & & \\
\hline
\end{tabular}

factors (Loubes, 1999). A particular concentration is effective for multiplication of spore and mortality (Graaf et al., 1994 ) and below that threshold level the concentrations do not cause any larval mortality (Larson, 1999). Therefore, the number of spores (intensity of infection) that a host can harbour and still function normally is important in determining the role of microsporidia as a parasite in nature (Graaf et al., 1994 ). We have also found in our previous study that spore production reached the stationary phase in female during pupal stage to moth stage where as it is continued in progress in male pupa to moth stage till the dead of the moth i.e., the time of harvest. It is an interesting phenomenon of $N$. bombycis which needs to instigate further for detailed understanding and the findings assume importance for taxonomic classification (Chakrabarty et al., 2013a).

\section{Conclusion}

From the study, it may be concluded that both male and female moths to be examined microscopically during hybrid laying preparation. We could observe only $4^{\text {th }}$ generation from parental generation (P3) to commercial rearing in the field. As there is no chance for $6^{\text {th }}$ generation study in the field, for that reason outbreak of pebrine disease from secondary transmission is not observed. However, we should take care where parental generation (P3, P2 and P1) is maintained to check the secondary transmission. Besides, new management system using 'Sericillin' as bed disinfectant with 'fumigant chemicals' as room disinfectant is required to be adopted, especially where parental generation is maintained i.e., seed production centre, to control the secondary transmission of pebrine disease.

\section{References}

Cali A (1970) Morphogenesis in the genus Nosema. In: Proceedings of the $4^{\text {th }}$ International Colloquium Insect Pathology, Maryland, 1970, p. 431-8.

Chakrabarty S, Saha AK, Manna B, Bindroo BB (2013a) Gender influenced dimorphism in Nosema bombycis Nageli, causing pebrine disease in silkworm,Bombys mori L. Walilak J.Sci.Tech., Thailanad ( Ref : 303 -1065 -1-SP.DOC 2012-03-09) (ISSN:16863933 ). Online ISSN: 2228-835X_http://wjst.wu.ac.th.

Chakrabarty S, Saha AK, Bindroo BB, Manna B, Nirmal Kumar S (2013b) An improved method for detection of pebrine (Nosema bombycis N.) in silkworm (Bombyx mori). Appl. Biol. Res. 15(2), 1-6. Chapman HC, Woodard DB, Kellen WR, Clark TB (1996) Host parasite relationship of Thelohania associated with mosquitoes in Louisiana (Nosematidae: Microsporidia). J. Invertebr. Pathol. 8, 452-456.

Graaf DCD, Raes H, Jacobs FJ (1994) Note: Spore dimorphism in Nosema apis (Microsporidia: Nosematidae) Development cycle. J.Invertebr. Pathol., 63(1), 92-94.

Ishiwara R (1969) The life cycle of Nosema bombycis as revealed in tissue culture cells of Bombyx mori. J. Invertebr. Pathol. 7, 126-136.

Kawarabata T, Ishihara R (1984) Infection of development of Nosema bombycis (Microsporidia: Protozoa) in a cell line of Antheraea eucalypti. J. Invertebr. Pathol, 44, 52-62.

Kellen WR, Chapman HC, Clark JB, Lindergren JE (1965) Host parasite 
relationships of some Thelohania from mosquitoes (Nosematidae : Microsporidia). J. Invertebr. Pathol. 7, 161-166.

Lai PF, Canning EU (1983) Some factors affecting spore replications of Nosema algerae (Microspora, Nosematidae) in Pieris brassica (Lepidoptera). J. Invertebr. Pathol. 41, 20-26.

Larson RJI (1999) Identification of Microsporidia. Acta Protozool., 38: 161-197.

Loubes C, Maurand J, Ormmieres R (1999) Etude ultrastructurale de Spraguae lophii (Doflein), Microsporidae parasite de Baudroie: Essai d'interpretation du dimorphisme sporae. Parasitologica, 15, 43-54.
Pasteur L (1870). Etudes Surla Maladie Des Vers a'Soie. In : Pebrine disease of silkworm, Overseas Technical Cooperation Agency, Japan.

Pati CS (1993). Review of pebrine, a microsporidian disease in the silkworm, Bombyx mori L. Sericologia, 33(2), 201-210.

Steinhaus EA, Huges KM (1949) Two newly described species of Microsporidia from the potato tuberworm, Gnorimoschema operculella, Zellar (Lepidoptera: Gelechiidae). J. Parasitol. 35, 57-65.

Undeen AH (1997) A Handbook of Biology and Research Technique. In : Microsporidia (Protozoa) ( Millar,J.D. Ed.), Oklahama University, Southern Cooperative Series, Bulletin No.387. p -14. 